Check for updates

Cite this: RSC Adv., 2019, 9, 15004

\title{
Superior performance and mechanism of chlorobenzene degradation by a novel bacterium
}

\author{
Shihan Zhang, ${ }^{\text {ab }}$ Zanyun Ying, ${ }^{a}$ Juping You, ${ }^{a}$ Jiexu Ye, (D)*ab Zhuowei Cheng, ${ }^{\text {ab }}$ \\ Dongzhi Chen ${ }^{\text {ab }}$ and Jianmeng Chen ${ }^{\text {ab }}$
}

A newly isolated strain was identified as Ochrobactrum sp. by $16 \mathrm{~S}$ rRNA sequence analysis and named as ZJUTCB-1. The strain was able to degrade mono-chlorobenzene (CB) as the sole carbon and energy source under aerobic conditions. This study is the first to report the degradation of $C B$ by the genus Ochrobactrum. The degradation rate of $C B$ reached $170.9 \mu \mathrm{mol} \mathrm{L} \mathrm{L}^{-1} \mathrm{~h}^{-1}$, which is at least 6 times higher than the previously reported data. The strain can efficiently degrade CB under a rang of temperatures $\left(30-40{ }^{\circ} \mathrm{C}\right.$ ) and $\mathrm{pH}(6.0-7.0)$ with optimum at $40{ }^{\circ} \mathrm{C}$ and $\mathrm{pH}$ 7.0. Salt concentration higher than $0.05 \mathrm{~mol} \mathrm{~L}^{-1}$ remarkably reduced the biodegradation capability. Moreover, true oxic condition was not an essential element for biodegradation given that the CB degradation rate of $210.4 \mu \mathrm{mol} \mathrm{L} \mathrm{L}^{-1} \mathrm{~h}^{-1}$ was obtained under microaerobic condition. Based on the Haldane kinetic model, the maximum specific growth rate was $0.895 \mathrm{~h}^{-1}$, which is the highest in ever described $\mathrm{CB}$-degrading strains. According to GC-MS analysis and enzymatic assay, CB was degraded via the meta-cleavage pathway by using 2,3dioxygenase and 2-chlorophenol as the main intermediates, producing $\mathrm{CO}_{2}$ and $\mathrm{Cl}^{-}$as the final products. The great performance of CB degradation by Ochrobactrum sp. ZJUTCB-1 provided an alternative for development of more effective and reliable biotreatment process.

Received 17th February 2019

Accepted 5th May 2019

DOI: $10.1039 / c 9 r a 01229 j$

rsc.li/rsc-advances excellent CB-degrading capability is critical and has attracted considerable interest.

Scholars have isolated several CB-degrading bacteria, such as Rhodococcus phenolicus sp. G2 $\mathrm{P}^{\mathrm{T}}$, Pseudomonas aeruginosa, Ralstonia pickettii L2, Acidovorax avenae, Escherichia hermanii, Planococcus sp. strain ZD22, Bacillus sp. TAS6CB, Brevibacillus agri DH-1, and Pandoraea pnomenusa sp. strain MCB032. ${ }^{\mathbf{1 6 - 2 4}}$ These strains obtained aerobic degradation rate of $0.318-3.66 \mathrm{mg} \mathrm{L}^{-1}$ $\mathrm{h}^{-1} \mathbf{1 8}^{\mathbf{1 8 2}, 25-27}$ However, their microbial activities remain insufficient to meet the demand for effective large-scale applications. Therefore, microorganisms with better CB-degrading ability are still urgently required. In addition, since microorganisms might expose to low dissolved oxygen due to the insufficient aeration, it is necessary to pay attention to the degradation rate of bacteria under microaerobic conditions.

The major pathway for $\mathrm{CB}$ degradation is initiated with a dioxygenases, TecA. ${ }^{28}$ The resulting dihydrodiols are rearomatized by dihydrodiol dehydrogenases, encoded by tecB genes, ${ }^{29}$ to chlorocatechols, which serve as the ring-fission substrate. The ring of chlorocatechols are cleaved in the ortho position by 1,2-dioxygenase (products of $c l c$ gene cluster) or in the meta position by 2,3-dioxygenase (products of $c b z E$ genes). ${ }^{30,31}$ On the other hand, Zhang et al. ${ }^{18}$ found that $R$. pickettii L2 degraded CB via initial mono-oxygenation rather than dioxygenation, generating 2-chlorophenol as the first intermediate. Hence, the metabolic pathways are diversity, depending on the type of degrading bacteria. Therefore, the
${ }^{a}$ College of Environment, Zhejiang University of Technology, Hangzhou, 310014, China. E-mail: yejiexu@zjut.edu.cn; Fax: +86-571-88320882; Tel: +86-571-88320853 ${ }^{b}$ Key Laboratory of Microbial Technology for Industrial Pollution Control of Zhejiang Province, Zhejiang University of Technology, Hangzhou, 310014, China 
degradation pathway should be determined for a novel strain that can utilize CB as the sole carbon and energy source.

This work focuses on: (1) the isolation and characterization of a new bacterium with superior CB degradation ability, (2) investigating the effect of initial $\mathrm{CB}$ concentration, $\mathrm{pH}$, temperature, salt concentration, initial cell concentration, and dissolved oxygen concentration on CB biodegradation, (3) determination of the $\mathrm{CB}$ degradation kinetics, and (4) proposing the CB degradation pathway.

\section{Experimental section}

\section{Chemicals and medium}

CB ( $\geq 99 \%)$ and ethyl acetate $(\geq 99.5 \%)$ were acquired from Shanghai Lingfeng Chemical Reagent Co., Ltd., China. Catechol ( $\geq 99.5 \%$ ) and Brilliant Blue G250 were acquired from Shanghai Aladdin Bio-Chem Technology Co., Ltd., China. $\mathrm{Na}_{2} \mathrm{HPO}_{4}$ $\cdot 12 \mathrm{H}_{2} \mathrm{O}$ and $\mathrm{NaH}_{2} \mathrm{PO}_{4} \cdot 2 \mathrm{H}_{2} \mathrm{O}$ with purity over $99 \%$ were provided by Guangdong Guanghua Chemical Factory Co., Ltd., China. $\left(\mathrm{NH}_{4}\right)_{2} \mathrm{SO}_{4}, \mathrm{MgSO}_{4}, \mathrm{~K}_{2} \mathrm{SO}_{4}$, and $\mathrm{NaCl}$ with purity over 99\% were obtained from Shanghai Shisihewei Chemical Co., Ltd., China. Yeast extract and tryptone were obtained from Nuoyang Biotechnology Company, China. Agar and 2-chlorophenol were obtained from Sinopharm Chemical Reagent, China. All other chemical agents (analytical grade) were obtained from Huipu Chemical Co., Ltd., China.

The employed minimal salt medium (MSM) contains $(1 \mathrm{~L})$ : $0.66 \mathrm{~g}\left(\mathrm{NH}_{4}\right)_{2} \mathrm{SO}_{4}, 0.11 \mathrm{~g} \mathrm{MgSO}_{4}, 0.12 \mathrm{~g} \mathrm{~K} \mathrm{SO}_{4}, 22.20 \mathrm{~g} \mathrm{Na} \mathrm{HPO}_{4}{ }^{-}$

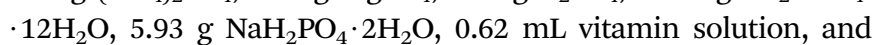
$1.25 \mathrm{~mL}$ trace element solution. The composition of the vitamin solution was based on our previous work. ${ }^{14}$ The trace element solution includes $(1 \mathrm{~L}): 0.01 \mathrm{~g} \mathrm{H}_{3} \mathrm{BO}_{3}, 0.1 \mathrm{~g} \mathrm{CaCl}_{2} \cdot 2 \mathrm{H}_{2} \mathrm{O}, 0.01 \mathrm{~g}$ $\mathrm{CuSO}_{4} \cdot 5 \mathrm{H}_{2} \mathrm{O}, 0.024 \mathrm{~g} \mathrm{NiCl} \cdot 6 \mathrm{H}_{2} \mathrm{O}, 0.025 \mathrm{~g} \mathrm{Na} \mathrm{WO}_{4} \cdot 2 \mathrm{H}_{2} \mathrm{O}, 0.025 \mathrm{~g}$ $\mathrm{Na}_{2} \mathrm{MoO}_{4}, 0.1 \mathrm{~g} \mathrm{CoCl}_{2} \cdot 6 \mathrm{H}_{2} \mathrm{O}, 0.1 \mathrm{~g} \mathrm{FeSO}_{4} \cdot 7 \mathrm{H}_{2} \mathrm{O}, 0.01 \mathrm{~g}$ AlK $\left(\mathrm{SO}_{4}\right)_{2} \cdot 12 \mathrm{H}_{2} \mathrm{O}, 0.13 \mathrm{~g} \mathrm{ZnCl} 2,0.5 \mathrm{~g} \mathrm{MnSO}_{4} \cdot \mathrm{H}_{2} \mathrm{O}, 1 \mathrm{~g} \mathrm{NaCl}, 1.5 \mathrm{~g}$ NTA and $3 \mathrm{~g} \mathrm{MgSO}_{4}$. The $\mathrm{pH}$ value of the MSM (without the addition of the trace element and vitamin solution) was set to 7.0 by adding $1 \mathrm{~mol} \mathrm{~L}{ }^{-1} \mathrm{NaOH}$ solution. The MSM was sterilized at $110{ }^{\circ} \mathrm{C}$ for $40 \mathrm{~min}$. The trace mineral and vitamin solutions were filtered after being disposed and transferred to MSM. The Luria-Bertani (LB) medium contains $(1 \mathrm{~L}): 5.0 \mathrm{~g}$ yeast extract, $10.0 \mathrm{~g} \mathrm{NaCl}$, and $10.0 \mathrm{~g}$ tryptone. Before use, the LB medium was sterilized for $20 \mathrm{~min}$ at $121{ }^{\circ} \mathrm{C}$. All the solid media contain $2 \mathrm{wt} \%$ agar.

\section{Isolation of the strain ZJUTCB-1}

An activated sludge obtained from a Hangzhou wastewater treatment plant was used to isolate the strain. The activated sludge was inoculated in MSM containing $100 \mathrm{mg} \mathrm{L}^{-1} \mathrm{CB}$ at $30^{\circ} \mathrm{C}$ and $160 \mathrm{rpm}$ to enrich the bacterium. When the CB concentration was decreased by $50 \%$, the solution was displaced using fresh medium containing $100 \mathrm{mg} \mathrm{L}^{-1} \mathrm{CB}$. After repeating the operation for five times, the diluted enrichment liquid was coated on solid MSM with CB for 3-5 days at $30{ }^{\circ} \mathrm{C}$. Hereafter, a single colony selected from solid MSM was inoculated to the fresh LB liquid medium. The obtained pure culture was added to the fresh MSM with CB to test its capability for CB degradation. The bacterium was designated as strain ZJUTCB-1.

The strain ZJUTCB-1 was identified by $16 \mathrm{~S}$ rRNA analysis. A kit of DNA extraction (Sangon, Shanghai, China, SK8255) was used to extract genomic DNA of the strain according to the manufacturer's instruction. The $16 \mathrm{~S}$ rRNA sequence was amplified via polymerase chain reaction (PCR) for 30 cycles by using universal forward and reverse primers such as CAGAGTTTGATCCTGGCT and AGGAGGTGATCCAGCCGCA. The PCR program was carried out as follows: denaturing for $4 \mathrm{~min}$ at $94{ }^{\circ} \mathrm{C}$ and then running 30 cycles of $45 \mathrm{~s}$ at $94{ }^{\circ} \mathrm{C}$ (denaturation), $45 \mathrm{~s}$ at $55{ }^{\circ} \mathrm{C}$ (annealing), and $1 \mathrm{~min}$ at $72{ }^{\circ} \mathrm{C}$ (extension). The resulting product was sequenced by the Shanghai Sangon Biotech Co., Ltd., China. The obtained sequence was in comparison with that reported in the GenBank database via the BLAST program. A phylogenic tree was established using MegAlign software (MEGA 5.1).

\section{CB degradation experiments and kinetics experiments}

The strain ZJUTCB-1 was pre-grown in MSM with CB at $30{ }^{\circ} \mathrm{C}$ to late exponential growth phase and then collected via centrifugation (10 $000 \mathrm{rpm}, 3 \mathrm{~min}, 4^{\circ} \mathrm{C}$ ). The harvested cells were resuspended in MSM for further use after washing with MSM thrice.

In a typical test, the degradation experiment was conducted in $340 \mathrm{~mL}$ serum vials with $50 \mathrm{~mL}$ MSM containing 520-2600 $\mu \mathrm{mol} \mathrm{L}^{-1} \mathrm{CB}$ and 24-62 mg DCW L ${ }^{-1}$ ZJUTCB-1 (160 rpm) under aerobic condition ( $\left.\sim 7 \mathrm{mg} \mathrm{L^{-1 }} \mathrm{DO}\right) . \mathrm{N}_{2}$ with high purity was passed into the serum vials for $30 \mathrm{~min}$ to achieve a microaerobic condition $\left(\sim 0.2 \mathrm{mg} \mathrm{L}^{-1} \mathrm{DO}\right)$. For $\mathrm{pH}$ test, the initial $\mathrm{pH}$ of MSM was adjusted to 5.0, 6.0, 7.0, 8.0, and 9.0. To evaluate the effect of temperature, we varied the incubation temperature from 25$45{ }^{\circ} \mathrm{C}$. The effect of salt concentration on $\mathrm{CB}$ degradation was investigated using MSM containing 0-0.4 mol L ${ }^{-1} \mathrm{NaCl}$. Each group of experiments set up a blank control group (without bacterium). The samples in the liquid and gas phase were obtained at the certain interval. The degradation kinetics was also investigated under the cell concentration of $39 \mathrm{mg} \mathrm{DCW} \mathrm{L}^{-1}$ with different initial $\mathrm{CB}$ concentrations $\left(520-2600 \mu \mathrm{mol} \mathrm{L}{ }^{-1}\right)$ at $160 \mathrm{rpm}$ and $30^{\circ} \mathrm{C}$. The classical Haldane model was used to estimate the kinetics as follows: ${ }^{32}$

$$
\mu_{0}=\frac{1}{X} \frac{\mathrm{d} X}{\mathrm{~d} t}=\frac{\mu_{\mathrm{max}} S}{K_{\mathrm{s}}+S+S^{2} / K_{\mathrm{i}}}
$$

$$
\nu_{0}=\frac{1}{X} \frac{\mathrm{d} S}{\mathrm{~d} t}=\frac{\nu_{\max } S}{K_{\mathrm{s}}+S+S^{2} / K_{\mathrm{i}}}
$$

where $\mu_{0}$ and $\nu_{0}$ are the specific cell growth and CB degradation rate, respectively, $\mathrm{h}^{-1} ; \mu_{\max }$ and $\nu_{\max }$ are the maximum specific cell growth and degradation rate, $\mathrm{h}^{-1}$, respectively; $S$ is the concentration of $\mathrm{CB}, \mu \mathrm{mol} \mathrm{L}{ }^{-1} ; X$ is the concentration of strain ZJUTCB-1, mg DCW L ${ }^{-1} ; K_{\mathrm{i}}$ is the inhibition constant, $\mu \mathrm{mol} \mathrm{L}^{-1}$, and $K_{\mathrm{s}}$ is the half-saturation constant, $\mu \mathrm{mol} \mathrm{L}{ }^{-1}$.

\section{Enzyme assays}

The bacteria were harvested by centrifugation $(10000 \mathrm{rpm}$, $10 \mathrm{~min}, 4^{\circ} \mathrm{C}$ ), washed twice with $50 \mathrm{mmol} \mathrm{L}^{-1}$ phosphate buffer 
$(\mathrm{pH}=7.2)$, and suspended in phosphate buffer. The cells were broken by sonication and centrifuged at $12000 \mathrm{rpm}, 4^{\circ} \mathrm{C}$ for $30 \mathrm{~min}$. The precipitate was discarded, and the supernatant was kept on ice until use. The reaction system contained $0.3 \mu \mathrm{mol}$ catechol, $1.0 \mathrm{~mL}$ of $50 \mathrm{mmol} \mathrm{L}{ }^{-1}$ phosphate buffer, and cell extract (0.3-0.9 $\mathrm{mg}$ of protein) in a final volume of $3 \mathrm{~mL}$. The mixtures were reacted in water bath $\left(30{ }^{\circ} \mathrm{C}\right)$ for $10 \mathrm{~min}$. When cis,cis-muconic acid and 2-hydroxymuconic semialdehyde were formed, the absorbance at 260 and $375 \mathrm{~nm}$ increased, respectively.

Specific enzyme activities were calculated using the extinction coefficient of each reaction product: $16800 \mathrm{~L} \mathrm{~mol}^{-1} \mathrm{~cm}^{-1}$ for cis,cis-muconic acid at $260 \mathrm{~nm}$ and $36000 \mathrm{~L} \mathrm{~mol}^{-1} \mathrm{~cm}^{-1}$ for 2-hydroxymuconic semialdehyde at $375 \mathrm{~nm} \cdot{ }^{33,34}$ Specific enzyme activities were expressed in $\mu \mathrm{mol}$ of product formed per min per $\mathrm{mg}$ of protein. ${ }^{35}$ The content of protein in the cell-free extract was determined using the Bradford method. ${ }^{36}$

\section{Analytical methods}

The concentrations of $\mathrm{CO}_{2}$ and $\mathrm{CB}$ in the gas phase were determined using the $6890 \mathrm{~N}$ gas chromatograph (Agilent Technologies, America). For CB analysis, it was measured by a column of HP-INNOWax and flame ionization detector under air and hydrogen flow rates of 450 and $40 \mathrm{~mL} \mathrm{~min}^{-1}$, respectively. The inlet was in split mode with $\mathrm{N}_{2}$ as carrier gas (33.4 $\mathrm{mL} \mathrm{min}^{-1}$ ). The temperatures of the injector, detector, and oven were 200,180 , and $100{ }^{\circ} \mathrm{C}$, respectively. $\mathrm{CO}_{2}$ was measured using a thermal conductivity detector and a column of HP-Plot$\mathrm{Q}$ with helium as carrier gas $\left(2 \mathrm{~mL} \mathrm{~min}^{-1}\right)$. The temperatures of the injector, detector, and oven were 90,180 , and $40{ }^{\circ} \mathrm{C}$.

The concentration of $\mathrm{Cl}^{-}$was measured using an ICS-2000 ion chromatograph (DIONEX, America) equipped with the Ionpac AS19-HC column. The eluent was $\mathrm{KOH}$ with a concentration of $20 \mathrm{mmol} \mathrm{L}^{-1}$ at a flow rate of $1.00 \mathrm{~mL} \mathrm{~min}^{-1}$.

The intermediate products were identified by GC-MS (Agilent 7890N/MS 5975, America), using a column of HP-5MS and helium as the carrier gas $\left(1.5 \mathrm{~mL} \mathrm{~min}^{-1}\right)$. The temperature of the injector was $250{ }^{\circ} \mathrm{C}$. The temperature of the oven was maintained at $35{ }^{\circ} \mathrm{C}$ for $10 \mathrm{~min}$, ramped to $190{ }^{\circ} \mathrm{C}$ at $10{ }^{\circ} \mathrm{C} \min ^{-1}$, kept for another $2 \mathrm{~min}$, heated to $225{ }^{\circ} \mathrm{C}$ at $6{ }^{\circ} \mathrm{C} \mathrm{min}^{-1}$, and kept for another $1 \mathrm{~min}$. The mass spectrometer was operated in the electron impact mode. The electron ionization mass spectra were acquired at $70 \mathrm{eV}$ at ionization source temperature of $230{ }^{\circ} \mathrm{C}$. The intermediate products were determined and compared with the NIST standard library.

The cell concentration was determined by measuring the optical density at $600 \mathrm{~nm}$ by using a U-2910 spectrophotometer (HITACHI, Japan). The cell concentration was then calculated according to an established correlation between the absorbance and dry-weight concentration of strain ZJUTCB-1.

\section{Results and discussion}

\section{Identification of strain ZJUTCB-1}

The colonies of ZJUTCB-1 were light yellow with neat edges and smooth surface. The morphology of the bacterium was bacilli with parallel edges and round ends without flagellation. It was a Gram negative bacterium. A sequence of the 16S rRNA gene with 1425-bp fragment was submitted to the GenBank database (accession number: MH910616). As shown in Fig. 1, the strain ZJUTCB-1 was closely similar to the strain of the genus Ochrobactrum. The strain ZJUTCB-1 had the highest similarity (approximately 98\%) with Ochrobactrum anthropic ATCC 49188 (GenBank accession No. CP000758). As a result, it was initially assigned as Ochrobactrum sp., and has been deposited in the China Center for Type Culture Collection with accession number of CCTCC M 2018490.

Ochrobactrum sp. can decompose various environmental pollutants, including benzo[ $a]$ pyrene, di- $n$-butyl phthalate, phenanthrene, phenol, and tetrabromobisphenol A. ${ }^{3-41}$ To the best of our knowledge, the present work first described an Ochrobactrum sp. strain with CB degradation capability.

\section{CB degradation by Ochrobactrum sp. ZJUTCB-1}

Fig. 2 shows the CB degradation performance with different initial substrate concentrations under aerobic condition. As shown in Fig. 2a, the degradation of CB encountered a lag phase and then gradually increased within the timeframe of the operation, indicating that the enzyme pertinent to the $\mathrm{CB}$ degradation was an induced enzyme rather than a constitutive enzyme. Correspondingly, the cell concentration growth also encountered a lag phase with the feeding of CB (Fig. 2b). Moreover, it could be found that CB at all tested concentrations was completely degraded within $26 \mathrm{~h}$. The highest average degradation rate of $170.9 \mu \mathrm{mol} \mathrm{L}{ }^{-1} \mathrm{~h}^{-1}$ was obtained at 1216 $\mu \mathrm{mol} \mathrm{L}{ }^{-1} \mathrm{CB}$ degradation, which was at least 6 times of the reported data shown in Table 1. Ochrobactrum sp. ZJUTCB-1 exhibited the best CB degradation activity in ever described microorganisms.

\section{Factors affecting CB degradation}

Effects of $\mathbf{p H}$ and temperature. $\mathrm{pH}$ and temperature were generally considered to be the main factors affecting microbial growth and contaminant degradation. ${ }^{\mathbf{4 4 , 4 5}}$ The most suitable $\mathrm{pH}$ for CB degradation by strain ZJUTCB-1 was 7.0 (Fig. 3a). The cell growth rate and CB degradation rate were higher under slightly acidic conditions than under microalkaline conditions, demonstrating that the bacteria preferred slightly acidic and neutral environments. Fig. 3b shows that strain ZJUTCB-1 can efficiently degrade $\mathrm{CB}$ under $30-40{ }^{\circ} \mathrm{C}$ with an optimum degradation at $40{ }^{\circ} \mathrm{C}$. The $\mathrm{CB}$ degradation rate and cell growth rate rapidly reduced by $60 \%$ and $50 \%$, respectively, when the temperature increased to $45^{\circ} \mathrm{C}$. These phenomena were similar to the result reported in pervious study of Ochrobactrum sp. ${ }^{46}$ The key enzyme involved in the CB degradation lost its activity, which may be an important cause of low degradation rate under high temperature.

Effects of salt concentration. Fig. 4 shows that the cell growth rate and $\mathrm{CB}$ degradation rate reached the maximum at $\mathrm{NaCl}$ concentration of $0.05 \mathrm{~mol} \mathrm{~L}^{-1}$. With the increase of salt concentration, CB degradation rate decreased. The CB degradation rate at $\mathrm{NaCl}$ concentration of $0.4 \mathrm{~mol} \mathrm{~L}^{-1}$ was 


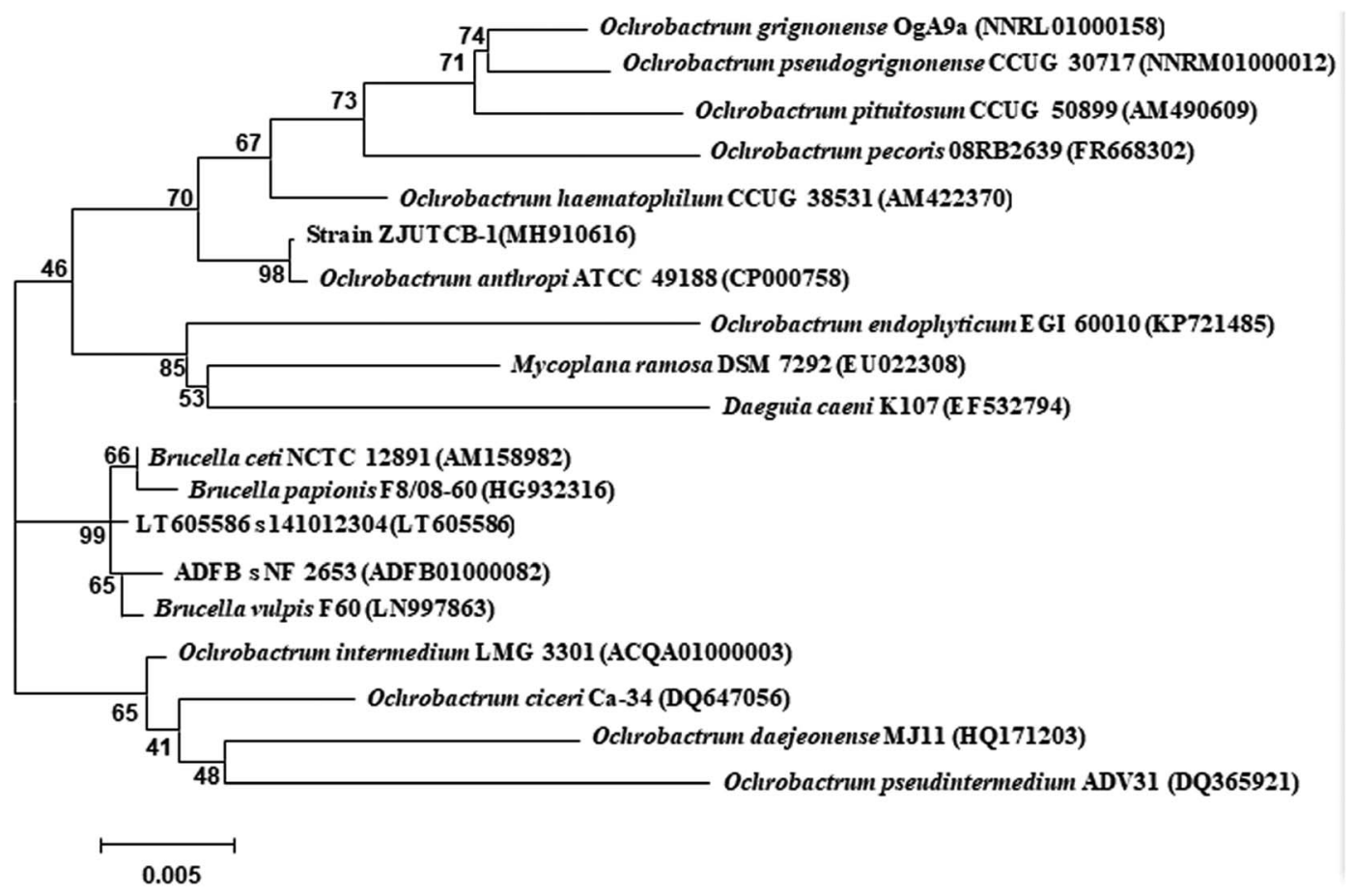

Fig. 1 Phylogenetic tree of 16S rRNA for the strain ZJUTCB-1.

approximately $30 \%$ of the degradation rate at $\mathrm{NaCl}$ concentration of $0.05 \mathrm{~mol} \mathrm{~L}^{-1}$, which may due to the cellular water loss or cytoplasm recession under high salt concentration. ${ }^{47}$ Correspondingly, the cell growth rate also had similar changes. Trace salinity was good for cell growth and CB degradation, whereas high salinity inhibited cell growth and $\mathrm{CB}$ degradation remarkably.

Effects of initial cell concentration. As shown in Fig. 5a and $\mathrm{b}$, when the initial cell concentration was increased from 24 to $54 \mathrm{mg}$ DCW L ${ }^{-1}$, the consumption rate of $\mathrm{CB}$ and the growth rate of strain ZJUTCB-1 were both accelerated by $\sim 200 \%$. However, initial cell concentration exceeding of $54 \mathrm{mg} \mathrm{DCW} \mathrm{L}^{-1}$ did not result in further noticeably increase in the degradation rate and cell growth rate. Therefore, conditions with a cell concentration of $54 \mathrm{mg} \mathrm{DCW} \mathrm{L}{ }^{-1}$ were the most favorable for $\mathrm{CB}$ degradation and cell growth.

Effect of dissolved oxygen concentrations. Fig. $6 a$ and $b$ show the CB degradation rate and cell growth rate with different initial substrate concentrations under aerobic and microaerobic conditions. Under both aerobic and microaerobic conditions, CB degradation rate as the function of the substrate concentration followed a reverse V-shape (Fig. 6a), indicating that $\mathrm{CB}$ inhibited the degradation at high $\mathrm{CB}$ concentration due to its toxicity. ${ }^{18}$ The relationship between substrate concentration and cell growth rate followed a pattern similar as the degradation (Fig. 6b). It was also noted that, compared with aerobic biodegradation, the strain ZJUTCB-1 had a similar ability to degrade $\mathrm{CB}$ when met with oxygen limitation. The
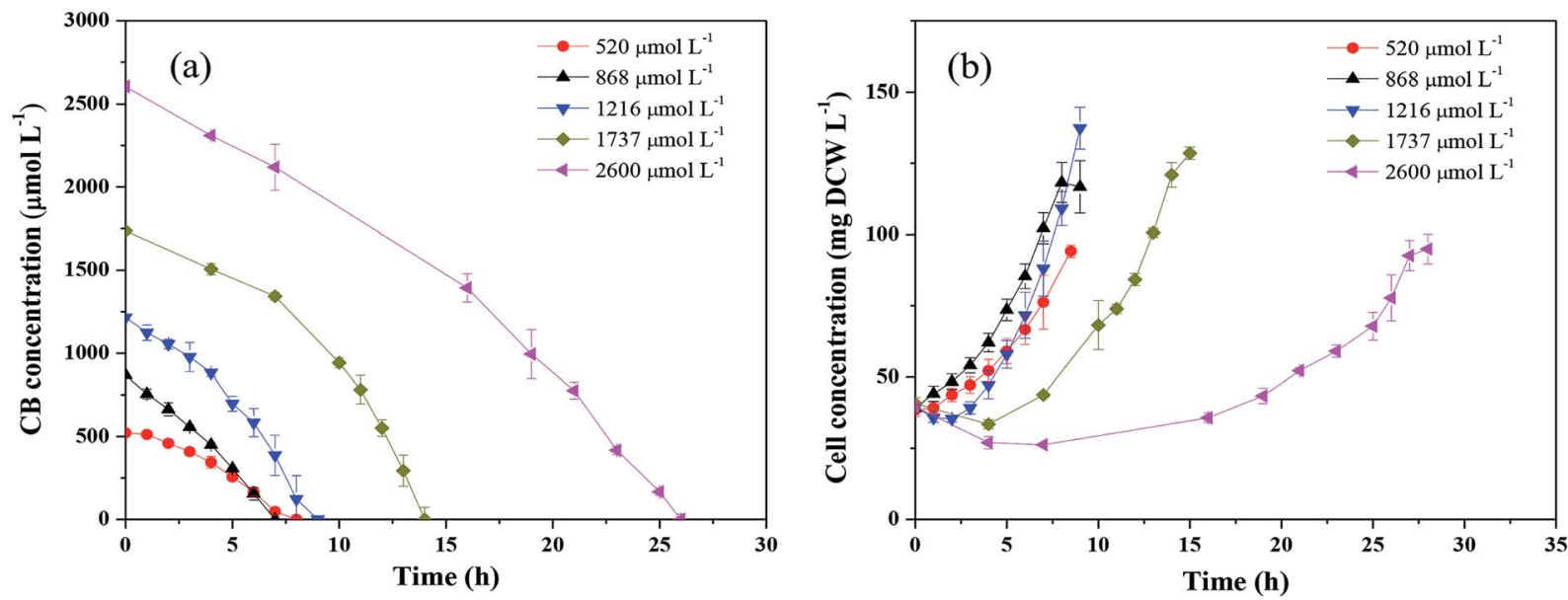

Fig. 2 Degradation of CB by Ochrobactrum sp. ZJUTCB-1 with different initial $\mathrm{CB}$ concentrations under aerobic condition $\left(\mathrm{pH}=7.0, T=30{ }^{\circ} \mathrm{C}\right.$, and $[\text { cell }]_{0}=39 \mathrm{mg} \mathrm{DCW} \mathrm{L}^{-1}$ ). 
Table 1 Performance of CB degradation by various microorganisms

\begin{tabular}{|c|c|c|c|c|c|c|c|}
\hline Culture & Condition & $\begin{array}{l}\text { CB concentration } \\
\left(\mathrm{mg} \mathrm{L}^{-1}\right)\end{array}$ & $\begin{array}{l}\text { Reaction } \\
\text { time }\end{array}$ & $\begin{array}{l}\text { Removal } \\
\text { efficiency (\%) }\end{array}$ & $\begin{array}{l}\text { Average degradation } \\
\text { rate }\left(\mathrm{mg} \mathrm{L}^{-1} \mathrm{~h}^{-1}\right)\end{array}$ & Temperature $\left({ }^{\circ} \mathrm{C}\right)$ & Ref. \\
\hline Ralstonia pickettii $\mathrm{L} 2$ & Aerobic & 220 & $75 \mathrm{~h}$ & 100 & 2.933 & 30 & 18 \\
\hline Escherichia hermanii & Aerobic & 394 & $300 \mathrm{~h}$ & 100 & 1.313 & 30 & 20 \\
\hline Planococcus sp. ZD22 & Aerobic & 112.5 & $120 \mathrm{~h}$ & 67.3 & 0.63 & 20 & 21 \\
\hline $\begin{array}{l}\text { Mixed fungal-bacterial } \\
\text { consortium }\end{array}$ & Aerobic & 220 & $60 \mathrm{~h}$ & 100 & 3.666 & 30 & 25 \\
\hline Labrys portucalensis $\mathrm{F} 11$ & Aerobic & 56 & $10 \mathrm{~d}$ & & $0.5 \pm 0.03$ & 25 & 27 \\
\hline Enrichment culture & Anaerobic & 225 & $50 \mathrm{~d}$ & 100 & 0.1875 & 30 & 42 \\
\hline Sediment culture & Anaerobic & 78.75 & $140 \mathrm{~h}$ & 100 & 0.5625 & & 43 \\
\hline Ochrobactrum sp. ZJUTCB-1 & Aerobic & 136.75 & $9 \mathrm{~h}$ & 100 & $19.23\left(170.9 \mu \mathrm{mol} \mathrm{L}^{-1} \mathrm{~h}^{-1}\right)$ & 30 & This work \\
\hline
\end{tabular}
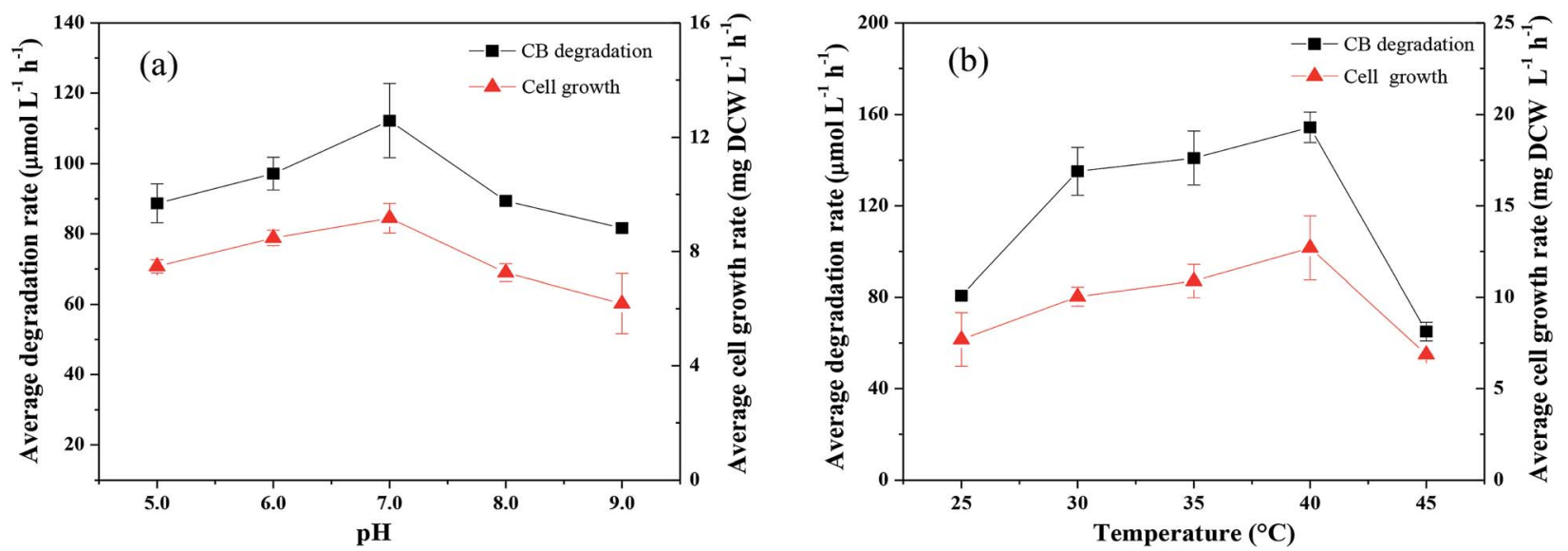

Fig. 3 Effects of $\mathrm{pH}(\mathrm{a})$ and temperature (b) on the degradation of $\mathrm{CB}$ and the growth of Ochrobactrum sp. ZJUTCB-1 ([CB $]_{0}=868 \mu \mathrm{mol} \mathrm{L}^{-1}$, and $[\text { cell] }]_{0}=39 \mathrm{mg} \mathrm{DCW} \mathrm{L}^{-1}$.

maximum average degradation rate of $\mathrm{CB}$ could reach 210.4 $\mu \mathrm{mol} \mathrm{L}{ }^{-1} \mathrm{~h}^{-1}$ under microaerobic condition (Fig. 6a). Thus, it could be concluded that a truly oxic condition was not an essential element for CB biodegradation by the strain ZJUTCB1. High oxygen affinities for some catabolic enzymes, such as the activity of catechol 2,3-dioxygenase, would decrease by increasing the oxygen level. ${ }^{48}$ The strain ZJUTCB-1 with good CB degradation performance under microaerobic conditions could reduce the aeration energy consumption in biological processes, and it could also be used for the bioremediation of groundwater and sediment.

\section{Kinetics of CB degradation by Ochrobactrum sp. ZJUTCB-1}

The Monod kinetic model and the Haldane kinetic model are commonly used to predict substrate degradation. ${ }^{49,50}$ Considering the substrate inhibition occurred at high CB concentration, the Haldane kinetic model was used to predict the aerobic biodegradation of CB in this work.

As shown in Fig. 7a, the Haldane kinetic model well fitted the experimental data $\left(R^{2}>0.95\right)$. The values of $\mu_{\max }, K_{\mathrm{s}}$, and $K_{\mathrm{i}}$ were $0.895 \mathrm{~h}^{-1}, 2495 \mu \mathrm{mol} \mathrm{L}{ }^{-1}$, and $697 \mu \mathrm{mol} \mathrm{L}^{-1}$, respectively. The specific growth rate of aerobic degradation initially increased and then decreased (Fig. 7a). This finding might indicate that the increasing available carbon source at concentrations below $1216 \mu \mathrm{mol} \mathrm{L}^{-1}$ was beneficial to bacterial growth. When the concentration was higher, the toxicity of $\mathrm{CB}$ inhibited cell growth. The maximum specific growth rate was more than two

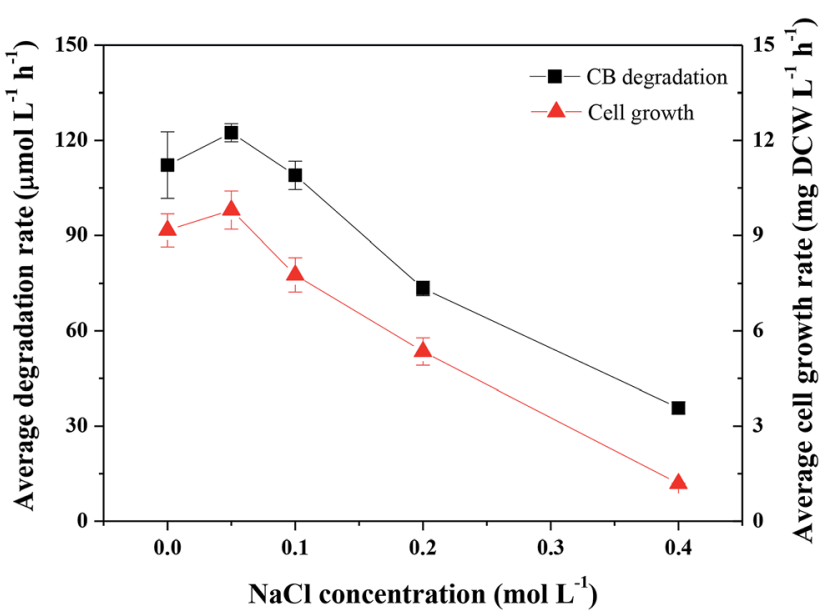

Fig. 4 Effects of salt concentration on the degradation of $C B$ and the growth of Ochrobactrum sp. ZJUTCB-1 $\left(\mathrm{pH}=7.0, T=30^{\circ} \mathrm{C},[\mathrm{CB}]_{0}=\right.$ $868 \mu \mathrm{mol} \mathrm{L}{ }^{-1}$, and [cell] $]_{0}=39 \mathrm{mg} \mathrm{DCW} \mathrm{L}^{-1}$ ). 

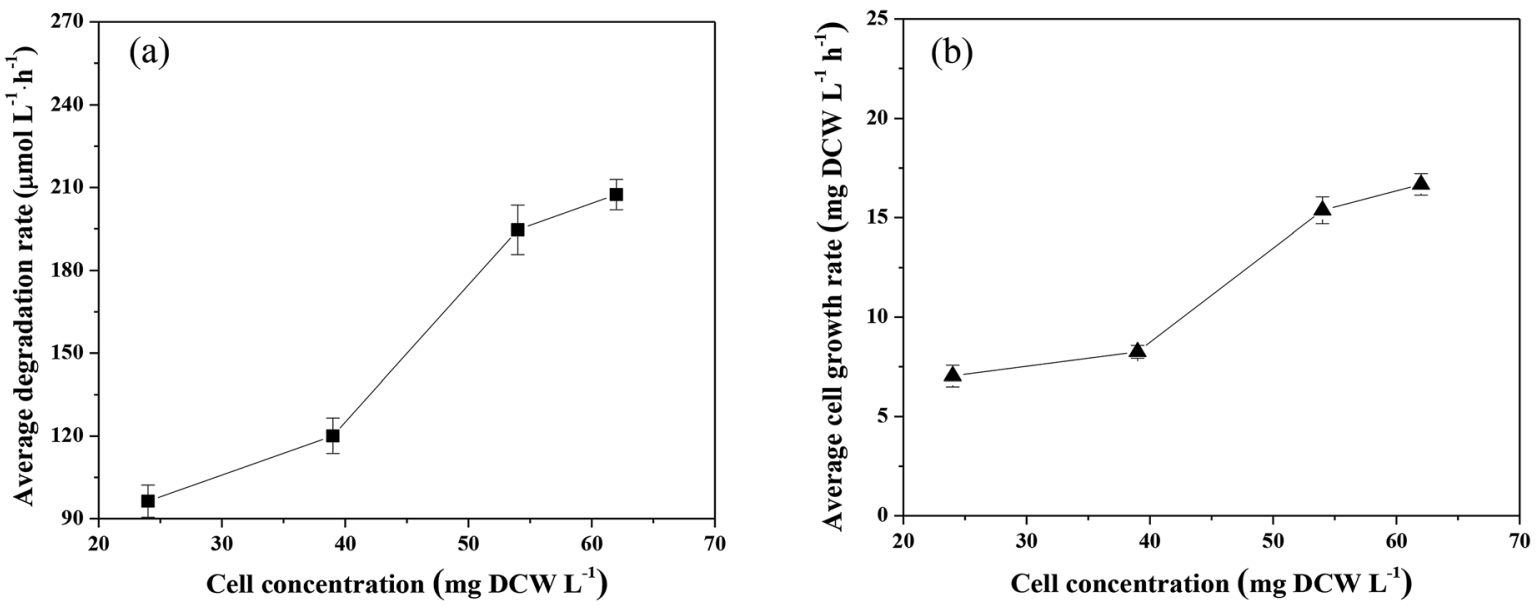

Fig. 5 Effects of initial cell concentration on the degradation of $\mathrm{CB}$ and the growth of Ochrobactrum sp. ZJUTCB-1 (pH $=7.0, T=30{ }^{\circ} \mathrm{C}$, and $[\mathrm{CB}]_{0}=868 \mu \mathrm{mol} \mathrm{L}^{-1}$ ).

times higher than that of the other aerobic degradation bacteria reported in the literatures $\left(0.15-0.36 \mathrm{~h}^{-1}\right) .^{24,25}$

Fig. $7 \mathrm{~b}$ shows the change in the specific degradation rate of strain ZJUTCB-1 at different CB concentrations in aerobic condition. The experimental data also well fitted to the Haldane kinetic model $\left(R^{2}>0.90\right)$. Similar to the growth kinetic, the degradation kinetics also showed the same tendency, confirming that $\mathrm{CB}$ inhibited the activity of $\mathrm{CB}$ degradation. The values of $v_{\max }, K_{\mathrm{s}}, K_{\mathrm{i}}$ were $3.315 \mathrm{~h}^{-1}, 2494.542 \mu \mathrm{mol} \mathrm{L}^{-1}$, and 697.149 $\mu \mathrm{mol} \mathrm{L}{ }^{-1}$, respectively. The maximum specific degradation rate with a cell concentration of $39 \mathrm{mg} \mathrm{DCW} \mathrm{L}^{-1}$ was approximately 11 times of the reported data. ${ }^{25}$

\section{CB degradation pathway of Ochrobactrum sp. ZJUTCB-1}

The pathway of CB degradation has been intensively investigated. ${ }^{15,51}$ In this work, the CB degradation pathway was also investigated. As shown in Fig. 8a, the characteristic peak of 2chlorophenol could be detected under aerobic condition by GCMS. The authenticity of the substance was confirmed by comparing the peak with the NIST library. Fig. $8 \mathrm{~b}$ shows the main intermediate and cell growth under aerobic condition at different time intervals. 2-Chlorophenol accumulated at the initial stage of $\mathrm{CB}$ degradation, reaching the highest concentration of $2.34 \mathrm{mg} \mathrm{L}^{-1}$ ( $3 \mathrm{wt} \%$ initial CB concentration) at $4 \mathrm{~h}$, and then gradually decreased. Meanwhile, noting that when the concentration of 2-chlorophenol decreased, the cell concentration still increased. These results confirmed that CB degradation proceeded with 2-chlorophenol as an intermediate. We inferred the degradation of $\mathrm{CB}$ was caused by monooxygenase, which initially produced 2-chlorophenol and then converted into 3-chlorocatechol. This step was similar to the result reported by Zhang et al. ${ }^{18}$ but was different from some previous works in which the degradation of CB was initiated by dioxygenase $^{43,52}$ The specific enzyme activity of 2,3-dioxygenase was measured to be $1.03 \mu \mathrm{mol} \mathrm{min}{ }^{-1} \mathrm{mg}^{-1}$ protein, while that of 1,2-dioxygenase was not detected, suggesting that 2,3-dioxygenase played a major role in CB degradation. Furthermore, chlorine ion concentration increased in the aqueous phase, and $93 \%$ of CB was dechlorinated at the end of experiments (Fig. 8c). Therefore, 3-chlorocatechol was deduced to be oxidized via meta-cleavage pathway to acylchloride. The resulting acylchloride was dechlorinated and converted into 4-
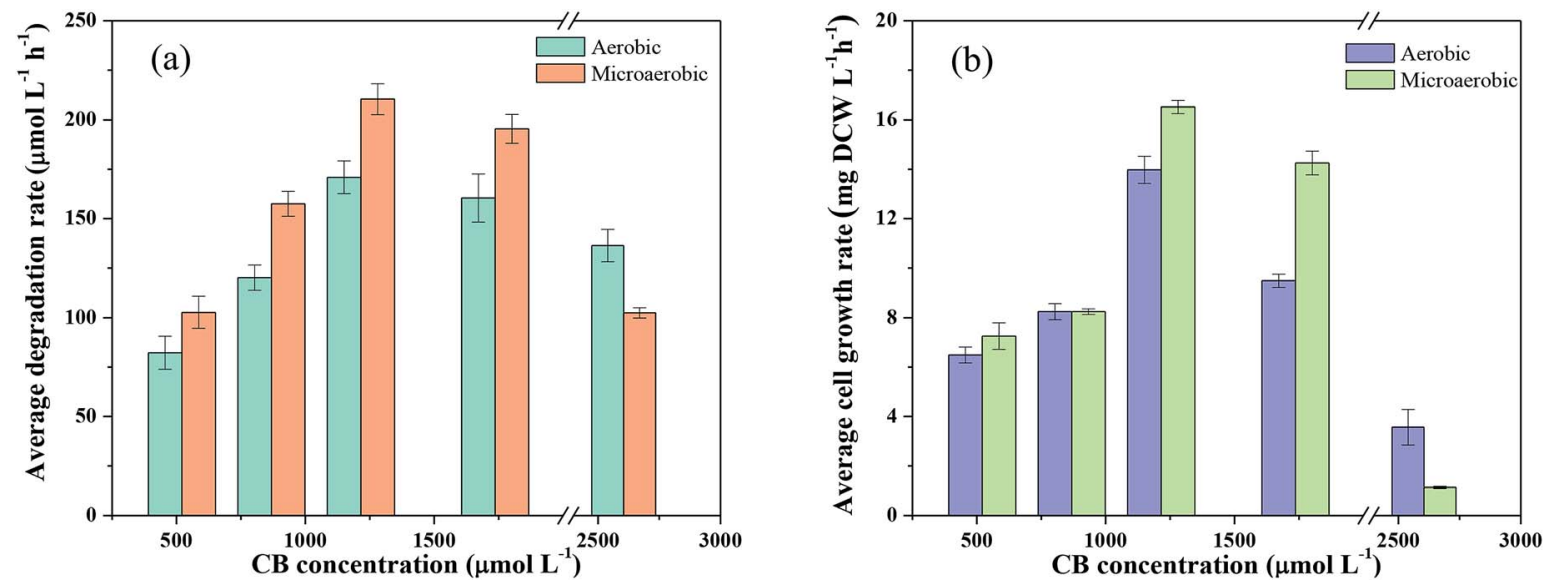

Fig. 6 Comparison of the degradation rate of CB (a) and the growth rate of Ochrobactrum sp. ZJUTCB-1 (b) under aerobic and microaerobic conditions $\left(\mathrm{pH}=7.0, T=30^{\circ} \mathrm{C}\right.$, and $\left.[\text { cell }]_{0}=39 \mathrm{mg} \mathrm{DCW} \mathrm{L}^{-1}\right)$. 

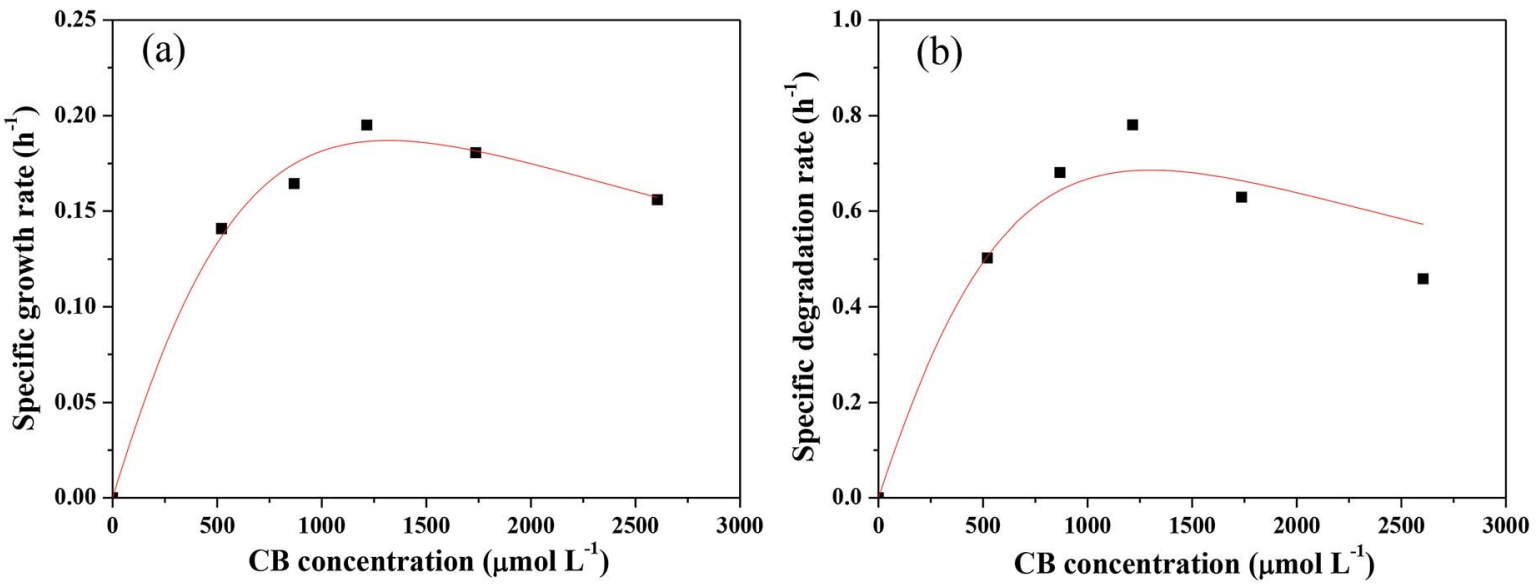

Fig. 7 Specific growth kinetic (a) and specific degradation kinetic (b) analysis of Ochrobactrum sp. ZJUTCB-1 (pH $=7.0, T=30{ }^{\circ} \mathrm{C}$, and $[\mathrm{cell}]_{0}=$ $39 \mathrm{mg} \mathrm{DCW} \mathrm{L}^{-1}$ ). The points represent the experimental data, and the lines represent the predicted data obtained from the Haldane kinetic model.

oxalocrotonate, which entered the Kreb's cycle subsequently. ${ }^{15,52}$ A possible pathway for CB degradation by Ochrobactrum sp. ZJUTCB-1 under aerobic condition was proposed in Fig. 9. Furthermore, the existence of 2,3-dioxygenase also confirmed that the great degradation performance of the strain ZJUTCB-1 under microaerobic conditions might be attributed to the high oxygen affinity of 2,3-dioxygenase.

The variation of carbon-based products, including the Cbiomass, $\mathrm{C}-\mathrm{CO}_{2}$, and $\mathrm{C}-2$-chlorophenol, during the aerobic degradation within $5 \mathrm{~h}$ was determined. As shown in Fig. 8d, the total carbon determined with $\mathrm{C}-\mathrm{CB}, \mathrm{C}-$ biomass, $\mathrm{C}-\mathrm{CO}_{2}$, and C2-chlorophenol decreased by $9.24 \%$, which suggested that several intermediates were undetectable. Under the cultivation time of $5 \mathrm{~h}, 39.3 \%$ of carbon from $\mathrm{CB}$ was converted into $\mathrm{CO}_{2}$, and a higher fraction $(43.4 \%)$ of carbon from CB was converted into biomass. These results further certified that the biomass assimilation and $\mathrm{CO}_{2}$ production were the two major fates of the carbon in the removed CB.
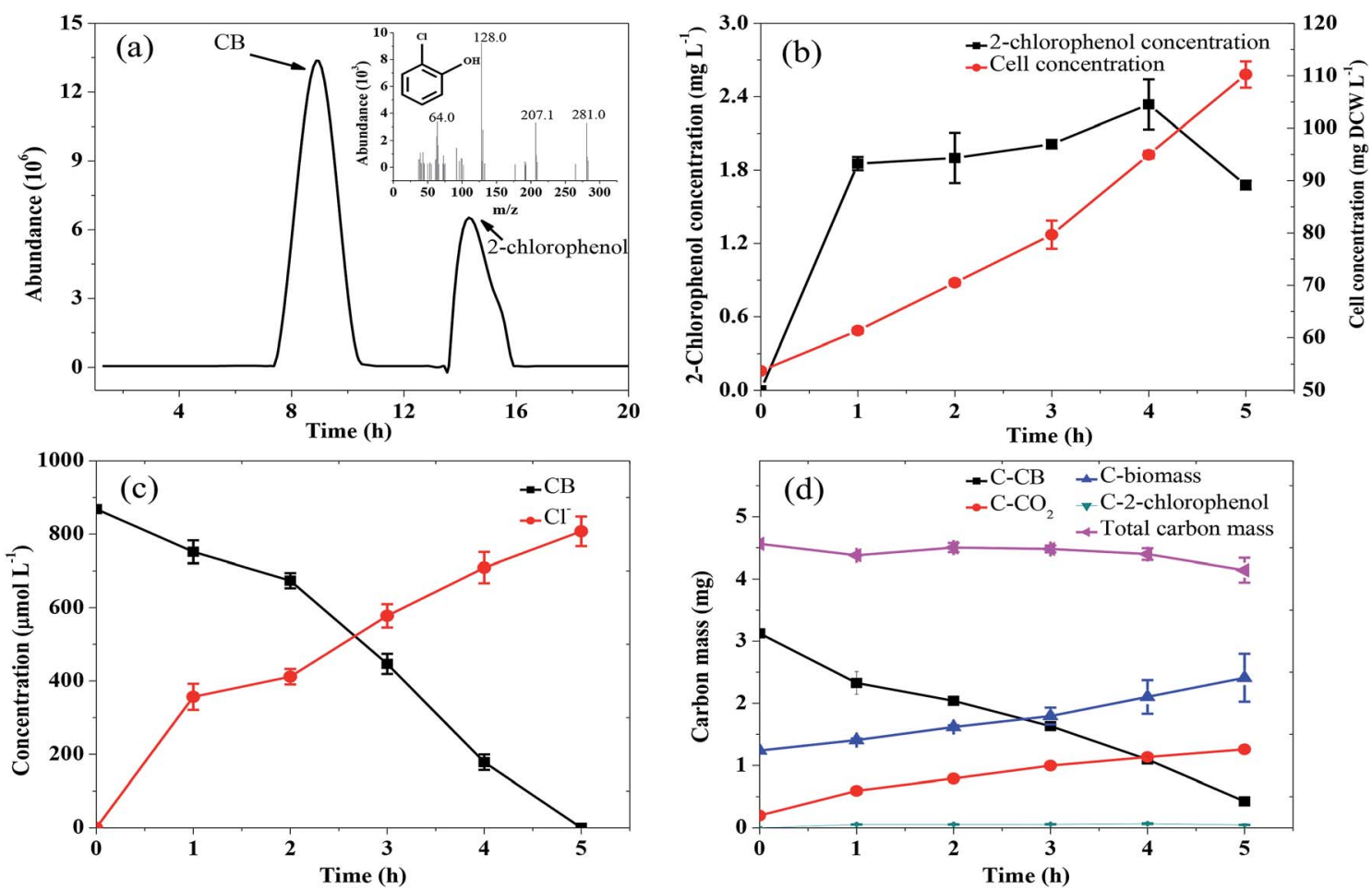

Fig. 8 Identification of CB degradation intermediates by Ochrobactrum sp. ZJUTCB-1. (a) Total ion chromatogram of the components in the medium after biodegradation for $4 \mathrm{~h}$, the insets in (a) show the electron ionization mass spectrum and the fragmentation patterns of the product detected at the retention time of $15.182 \mathrm{~min}$; (b) concentrations of 2-chlorophenol and cell during biodegradation; (c) concentrations of $\mathrm{Cl}^{-}$and $\mathrm{CB}$ during biodegradation; (d) carbon mass balance during $\mathrm{CB}$ degradation by strain ZJUTCB-1 $\left(\mathrm{pH}=7.0, T=30^{\circ} \mathrm{C}_{,}[\mathrm{CB}]_{0}=868 \mu \mathrm{mol} \mathrm{L}^{-1}\right.$, and [cell] $_{0}=54 \mathrm{mg} \mathrm{DCW} \mathrm{L}^{-1}$ ). 


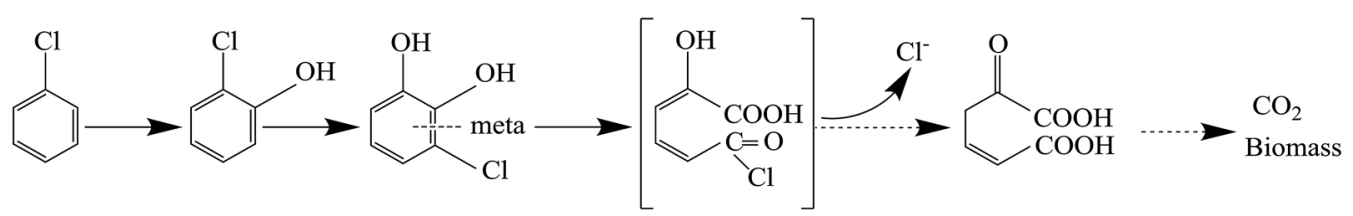

Fig. 9 Proposed pathway for CB degradation by Ochrobactrum sp. ZJUTCB-1 under aerobic condition.

\section{Conclusions}

The present work screened a new CB-degrading bacterium, and it was identified as Ochrobactrum sp. ZJUTCB-1. The isolate exhibited superior performance in aerobic CB-degrading activity with a maximum average degradation rate of 170.9 $\mu$ mol $\mathrm{L}^{-1} \mathrm{~h}^{-1}$. The strain can efficiently degrade $\mathrm{CB}$ under a range of temperatures $\left(30-40{ }^{\circ} \mathrm{C}\right.$ ) and $\mathrm{pH}$ (6.0-7.0) with optimum at $40{ }^{\circ} \mathrm{C}$ and $\mathrm{pH}$ 7.0. Salt concentrations higher than $0.05 \mathrm{~mol} \mathrm{~L}^{-1}$ remarkably reduced the biodegradation capability. CB degradation patterns were well described by Haldane model. Moreover, the truly oxic condition was not an essential element for the CB degradation by Ochrobactrum sp. ZJUTCB-1, because the degradation rate of $\mathrm{CB}$ did not decrease under oxygen limitation. 2-Chlorophenol was determined as the main intermediate and $\mathrm{Cl}^{-}$, and $\mathrm{CO}_{2}$ as the final products. $\mathrm{CB}$ was aerobically degraded via 2-chlorophenol into 3-chlorocatechol and subsequently subjected to the meta-cleavage pathway for further metabolism.

\section{Conflicts of interest}

There are no conflicts to declare.

\section{Acknowledgements}

This work was supported by the National Natural Science Foundation of China (No. 21876157, 21606204) and the Program for Changjiang Scholars and Innovative Research Team in University (IRT13096).

\section{References}

1 R. A. Pandey, P. R. Joshi, S. N. Mudliar and S. C. Deshmukh, Bioresour. Technol., 2010, 101, 5168-5174.

2 O. Lhotský, E. Krákorová, L. Linhartová, Z. Křesinová, J. Steinová, L. Dvořák, T. Rodsand, A. Filipová, K. Kroupová, L. Wimmerová, J. Kukačka and T. Cajthaml, Sci. Total Environ., 2017, 607-608, 1451-1465.

3 B. B. Feng, Y. X. Wei, Y. N. Qiu, S. F. Zuo and N. Ye, J. Rare Earths, 2018, 36, 1169-1174.

4 Y. Y. Guo, Y. R. Li, J. Wang, T. Y. Zhu and M. Ye, Chem. Eng. J., 2014, 236, 506-512.

5 P. T. Hoa, K. Suto, C. Inoue and J. Hara, AIP Conf. Proc., 2007, 898, 12-16.

6 L. Y. Jiang, G. F. Nie, R. Y. Zhu, J. D. Wang, J. M. Chen, Y. B. Mao, Z. W. Cheng and W. A. Anderson, J. Environ. Sci., 2017, 55, 266-273.
7 C. Luo, Z. Chen, D. L. Wu and L. M. Ma, Chem. Eng. J., 2014, 241, 376-383.

8 D. D. Pang, J. Gao, F. Ouyang, R. S. Zhu and C. Xie, Catalysts, 2017, 7, 126.

9 X. L. Weng, P. F. Sun, Y. Long, Q. J. Meng and Z. B. Wu, Environ. Sci. Technol., 2017, 51, 8057-8066.

10 W. Zhao and B. L. Shi, Sep. Sci. Technol., 2009, 44, 1737-1752.

11 M. A. Surhio, F. N. Talpur, S. M. Nizamani, F. Amin, C. W. Bong, C. W. Lee, M. A. Ashraf and M. R. Shah, RSC Adv., 2014, 4, 55960-55966.

12 Z. W. Cheng, X. M. Zhang, C. Kennes, J. M. Chen, D. Z. Chen, J. X. Ye, S. H. Zhang and D. D. Dionysiou, Sci. Total Environ., 2019, 650, 2095-2106.

13 J. P. You, M. Du, H. Chen, X. Y. Zhang, S. H. Zhang, J. M. Chen, Z. W. Cheng, D. Z. Chen and J. X. Ye, Int. Biodeterior. Biodegrad., 2018, 129, 202-208.

14 S. H. Zhang, J. P. You, N. An, J. K. Zhao, L. D. Wang, Z. W. Cheng, J. X. Ye, D. Z. Chen and J. M. Chen, Chem. Eng. J., 2018, 351, 515-522.

15 J. A. Field and R. Sierra-Alvarez, Biodegradation, 2008, 19, 463-480.

16 M. Rehfuss and J. Urban, Syst. Appl. Microbiol., 2005, 28, 695-701.

17 R. Manikandan, H. J. Prabhu and P. Sivashanmugam, J. Biotechnol., 2007, 6, 1338-1342.

18 L. L. Zhang, S. Q. Leng, R. Y. Zhu and J. M. Chen, Appl. Microbiol. Biotechnol., 2011, 91, 407-415.

19 M. V. Monferrán, J. R. Echenique and D. A. Wunderlin, Chemosphere, 2005, 61, 98-106.

20 J. Kiernicka, C. Seignez and P. Peringer, Lett. Appl. Microbiol., 1999, 28, 27-30.

21 H. Li, Y. H. Liu, N. Luo, X. Y. Zhang, T. G. Luan, J. M. Hu, Z. Y. Wang, P. C. Wu, M. J. Chen and J. Q. Lu, Res. Microbiol., 2006, 157, 629-636.

22 T. K. Vyas and S. R. Murthy, J. Basic Microbiol., 2015, 55, 382388.

23 B. R. Yang, Z. Q. Sun, L. P. Wang, Z. X. Li and C. Ding, Bioresour. Technol., 2017, 231, 19-25.

24 I. I. R. Baptista, N. Y. Zhou, E. A. C. Emanuelsson, L. G. Peeva, D. J. Leak, A. Mantalaris and A. G. Livingston, Biotechnol. Bioeng., 2008, 99, 68-74.

25 Z. W. Cheng, C. Li, C. Kennes, J. X. Ye, D. Z. Chen, S. H. Zhang, J. M. Chen and J. M. Yu, Int. Biodeterior. Biodegrad., 2017, 123, 276-285.

26 A. Kaschl, C. Vogt, S. Uhlig, I. Nuenhuis, H. Weiss, M. Kästner and H. H. Richnow, Environ. Toxicol. Chem., 2005, 24, 1315-1324.

27 I. S. Moreira, C. L. Amorim, M. F. Carvalho and P. M. L. Castro, Int. Biodeterior. Biodegrad., 2012, 72, 76-81. 
28 N. Kimura, W. Kitagawa, T. Mori, N. Nakashima, T. Tamura and Y. Kamagata, Appl. Microbiol. Biotechnol., 2006, 73, 474484.

29 K. Pollmann, S. Beil and D. H. Pieper, Appl. Environ. Microbiol., 2001, 67, 4057-4063.

30 X. W. Jiang, H. Liu, Y. Xu, S. J. Wang, D. J. Leak and N. Y. Zhou, Arch. Microbiol., 2009, 191, 485-492.

31 A. Alfreider, C. Vogt and W. Babel, Appl. Environ. Microbiol., 2003, 69, 1372-1376.

32 J. F. Andrews, Biotechnol. Bioeng., 1968, 10, 707-723.

33 E. Schmidt, G. Remberg and H. J. Knackmuss, Biochem. J., 2005, 192, 331-337.

34 J. A. Asturias and K. N. Timmis, Microbiology, 1993, 175, 4631-4640.

35 A. Farrell and B. Quilty, Biodegradation, 1999, 10, 353-362.

36 M. M. Bradford, Anal. Biochem., 1976, 72, 248-254.

37 Y. R. Wu, T. T. He, M. Q. Zhong, Y. L. Zhang, E. M. Li, T. W. Huang and Z. Hu, J. Environ. Sci., 2009, 21, 1446-1451.

38 X. L. Wu, Y. Y. Wang, R. X. Liang, Q. Y. Dai and W. L. Chao, Bull. Environ. Contam. Toxicol., 2010, 85, 235-237.

39 D. Ghosal, J. Chakraborty, P. Khara and T. K. Dutta, FEMS Microbiol. Lett., 2010, 313, 103-110.

40 W. S. El-Sayed, M. K. Ibrahim, M. Abu-Shady, F. El-Beih, N. Ohmura, H. Saiki and A. Ando, J. Biosci. Bioeng., 2003, 96, 310-312.

41 G. Y. Li, J. K. Xiong, P. K. Wong and T. C. An, Environ. Pollut., 2016, 208, 796-802.
42 J. L. Nelson, J. M. Fung, H. Cadillo-Quiroz, X. Cheng and S. H. Zinder, Environ. Sci. Technol., 2011, 45, 6806-6813.

43 X. M. Liang, M. R. Howlett, J. L. Nelson, G. Grant, S. Dworatzek, G. Lacrampe-Couloume, S. H. Zinder, E. A. Edwards and B. Sherwood Lollar, Environ. Sci. Technol., 2011, 45, 8321-8327.

44 M. H. El-Naas, S. A. Al-Muhtaseb and S. Makhlouf, J. Hazard. Mater., 2009, 164, 720-725.

45 B. Bhunia, B. Basak, T. Mandal and P. Bhattacharya, Int. J. Biol. Macromol., 2013, 54, 1-8.

46 Z. G. He, F. L. Gao, T. Sha, Y. H. Hu and C. He, J. Hazard. Mater., 2009, 163, 869-873.

47 T. Deng, H. Y. Wang and K. Yang, Water Sci. Technol., 2018, 77, 504-510.

48 Ö. Çinar, K. Demiröz, G. Kanat, Y. Uysal and C. Yaman, Clean: Soil, Air, Water, 2009, 37, 657-662.

49 J. L. Wang and W. Wan, Int. J. Hydrogen Energy, 2009, 34, 3313-3323.

50 A. Nuhoglu and B. Yalcin, Process Biochem., 2005, 40, 12331239.

51 M. Lapertot, C. Seignez, S. Ebrahimi and P. Peringer, Ind. Eng. Chem. Res., 2006, 45, 6778-6784.

52 A. E. Mars, T. Kasberg, S. R. Kaschabek, M. H. Van Agteren, D. B. Janssen and W. Reineke, J. Bacteriol., 1997, 179, 45304537. 